\title{
Association of Attention Deficit Hyperactivity Disorder Symptoms of Parents with Parental Attitudes
}

\author{
(D) Mehmet Çolak1, (10 Özlem Şireli Bingöl2, (1) Zeynep Esenkaya Usta33, (ㄱ) Birim Günay Kıllıç4 \\ ${ }^{1}$ Self-Employed Physician, Child and Adolescent Mental Health and Diseases, İzmir, Turkey \\ ${ }^{2}$ Self-Employed Physician, Child and Adolescent Mental Health and Diseases, Muğla, Turkey \\ ${ }^{3}$ Konya Training and Research Hospital, Clinic of Child and Adolescent Mental Health and Diseases, Konya, Turkey \\ ${ }^{4}$ Ankara University Faculty of Medicine, Department of Child and Adolescent Mental Health and Medicine, Ankara, Turkey
}

Cite this article as: Çolak M, Şireli Bingöl Ö, Esenkaya Usta Z, Kılıç BG. Association of Attention Deficit Hyperactivity Disorder Symptoms of Parents with Parental Attitudes. J Acad Res Med 2020;10(3):258-63

\begin{abstract}
Objective: The aim of this study was to examine the relationship between the level of attention deficit hyperactivity disorder (ADHD) symptoms and the attitudes of parents of children diagnosed with ADHD.

Methods: According to the Diagnostic and Numerical Manual of Mental Disorders-IV diagnostic criteria, 66 children with an age range of 6-13 were diagnosed with ADHD and their parents who brought them to the interview. A total of 94 parents were included in the study, including both the mother and father of some children diagnosed with ADHD, the mother of some, and the father of some. Parents of the children were evaluated with the "Wender-Utah Rating Scale (WURS)", "Parenting Styles and Dimensions Scale (PSDS-SF)".

Results: According to the results of our study; it was found that the permissive subscale scores of PSDS-SF were significantly higher in parents whose WURS scores were above the cut-off value compared to those whose WURS scores were below the cut-off value, and there was no significant difference between the two groups in terms of competent and authoritarian subscale scores of PSDS-SF. It was found that there was no significant association between parents' age and educational levels and their parent's attitudes. In addition, comparisons of parents in terms of ADHD symptom level and parental attitudes did not show significant differences between parents in terms of both variables.

Conclusion: The results of our study showed that permissive attitudes were significantly higher in parents with high levels of ADHD symptoms. In a clinical approach to children diagnosed with ADHD, it is believed that evaluating the symptoms and attitudes of parents with ADHD and psychoeducation of parents about adult ADHD are important for treatment.
\end{abstract}

Keywords: ADHD, adult ADHD, parental attitudes

\section{INTRODUCTION}

Attention deficit hyperactivity disorder (ADHD) is defined as a neurodevelopmental disorder characterized by decreased sustained attention, increased impulsivity, and/or mobility. It is quite common in children and adolescents and has been shown to have an average worldwide prevalence of $5.9-7.1 \%$ (1). ADHD, which begins in childhood, also persists in the adult period at a rate of $50-70 \%(2,3)$.

ADHD is a genetic transitive disorder, and the incidence of ADHD in the mothers and/or fathers of children with ADHD is high

ORCID IDs of the authors: M.Ç. 0000-0003-4880-3892; Ö.Ş.B. 0000-0002-5549-4154; Z.E.U. 0000-0003-0925-7868; B.G.K. 0000-0002-4566-2564 
compared to the healthy population. In Turkey, in 2005, a crosssectional study evaluating the parents of 69 ADHD diagnosed and monitored children found that $33.8 \%$ of parents met ADHD diagnostic criteria (4). Another recent study in Turkey evaluated 135 children with ADHD and 135 control groups and found that the level of ADHD symptoms of parents of children with ADHD was significantly higher than that of the control group (5). Overall, the lifetime prevalence of ADHD in adults is known to be 1.1-5\% $(6,7)$. Lifelong clinical features of ADHD are manifested in different forms in adults. Inattention causes symptoms in individuals such as forgetfulness, contemplation, inability to listen, difficulty in making decisions, lack of planning skills, inability to use time properly, failures in performing tasks, postponement or inability to finish work. While hyperactivity causes symptoms such as inner restlessness, tension, talking too much, not being able to sit for a long time; impulsivity causes symptoms such as taking action without thinking, inability to wait in line, constant attention seeking, frequent job and traffic accidents, frequent job and partner changes, and inappropriate sexual experiences (8). Adult $A D H D$, where the rate of co-diagnosis is also high, negatively affects people's relationships, work and family life $(9,10)$.

In general, the attitude of parents is defined as the whole of the attitudes and behaviors that parents display in their relationship with the child. Researchers evaluated parental attitudes in many dimensions, such as control, control, temperature, showing the necessary attention, open communication, and defined different classifications. Baumrind (11) defined three basic parenting attitudes as "democratic/balanced (authoritative)", "authoritarian (authoritarian)" and "permitting". In Democratic parental attitudes, open communication with the child and the necessary emotional support are provided; appropriate conditions are provided for the child to develop autonomy by keeping the child's behavior under supervision within a certain discipline. In authoritarian (authoritarian) parental attitudes, parents have a strict understanding of discipline, the child is not shown sufficient emotional support and warmth. In permissive parental attitudes, there is a weakness in controlling and controlling the child's behavior (11). According to the results of the research, while accepted democratic parental attitudes have positive effects on the development of the child, authoritarian and permissive attitudes have negative effects on many areas such as the child's self-development, emotion regulation and social adaptation (12).

In studies that examined the attitudes of parents, it was found that the parenting skills and attitudes of parents of adults with ADHD were negatively affected (13). A study conducted with 147 ADHD, 107 healthy children and their mothers to assess the relationship of mothers with ADHD diagnoses and attitudes found that mothers diagnosed with ADHD exhibit negative attitudes more often than other mothers, and have difficulty practicing consistent and effective discipline (14).

In another study conducted with 90 parents diagnosed with ADHD and 120 healthy groups in which parental attitudes were examined; it has been determined that parents with ADHD display more authoritarian attitudes and behave overly reactively than healthy parents, while parents in the control group have more permissive attitudes (15).

Although ADHD is a neurodevelopmental disorder, psychosocial factors such as parental attitudes are known to be important in terms of ADHD symptom severity and prognosis $(16,17)$. There are many studies in Turkey that assess parental attitudes in children with ADHD (18-25). However, there are limited studies evaluating the parental attitudes and parents in terms of ADHD symptoms in children with ADHD (26). The aim of this study is; to examine the relationship between the ADHD symptom level of parents of children diagnosed with ADHD and parental attitudes.

\section{METHODS}

\section{Sample}

In this study, 66 children who applied to Ankara University Faculty of Medicine, Department of Child and Adolescent Psychiatry Outpatient between March 2012 and August 2012, were diagnosed with ADHD according to Diagnostic and Statistical Manual of Mental Disorders (DSM-IV) diagnostic criteria, and their parents who brought them to the interview were included. A total of 94 parents, some of them both mothers and fathers, some only mothers and some only fathers of children with ADHD were included in the study. The presence of any chronic medical disease other than ADHD in children, concomitant diffuse developmental disorder, psychotic disorder, mental retardation (IQ lower than 80 ), and the presence of any chronic medical disease in parents were determined as exclusion criteria. In the study, the minimum sample width required to obtain $80 \%$ power $(1-\beta=0.80)$ at the nominal meaning level of $\alpha=0.05$ was determined as $n=94$ versus the effect size of $r=0.3$.

\section{Data Collection Tools}

Sociodemographic data form: This form prepared by researchers questions demographic information such as age of children, gender, age of parents, level of education.

Wender-Utah Rating Scale: This scale developed by Ward and Wender (1993); evaluates the presence and severity of childhood ADHD symptoms in adults. Its Turkish validity and reliability study was conducted by Öncü et al. (27). Wender-Utah Rating Scale (WURS) is a 5-point Likert type self-report scale consisting of 25 items. Each item is rated between 0 and 4 and the cut-off score of the scale is determined as 36 . Sensitivity was $82.5 \%$ and specificity was $90.8 \%$ when the breakpoint was taken 36 and above.

Parenting Styles and Dimensions Scale: This scale developed by Robinson et al.; evaluates the attitudes of parents with children between the ages of 3-13. Turkish validity and reliability studies of the scale were carried out by Kapçı and Erdinç (28). Parenting Styles and Dimensions Scale (PSDS-SF) consists of 32 items and is a 5-point Likert type self-report scale. Parents' attitudes are evaluated in three dimensions as "authoritative", "authoritarian" and "permissive". In reliability analysis, the Cronbach Alpha Coefficient was calculated as 0.88 for the competent subscale, 
0.74 for the competent subscale, and 0.64 for the permitting subscale. The test-retest reliability coefficient of the scale is 0.64 .

\section{Process}

The children and their parents in the study group were informed about the purpose and method of the study and their written consents were obtained. WURS and PSDS-SF scales were applied to the parents of children diagnosed with ADHD according to DSM-IV-TR.

\section{Statistical Analysis}

All data were evaluated using the SPSS Windows version 24.0 software. "Shapiro-Wilk test" and "Levene's test" were used for the suitability of the homogeneous variance assumption for the analysis of the suitability of the data for the normal distribution. In comparison of continuous variables, the "Student's t-test" was used when parametric assumptions were met, and the "MannWithney $U$ test" when parametric assumptions were not met. Relations of continuous variables were evaluated by the "Pearson correlation test" and relations of discrete and sequential variables were evaluated by the "Spearman Rho correlation test". P-value of $<0.05$ was considered statistically significant.

\section{RESULTS}

Of the children enrolled in the study, 14 (21.2\%) were girls, 52 $(78.8 \%)$ were boys, and the average age was $9.83 \pm 2.42$ years. Of the 94 parents included in the study, $54(57.4 \%)$ were mothers and $40(42.6 \%)$ were fathers. The mean age of the mothers was found to be $35.74 \pm 4.89$ years, and the average age of the fathers as $39.28 \pm 6.63$ years. When the education levels of the parents are evaluated; 3 of the mothers (5.6\%) were only literate, 17 (31.5\%) were primary school graduates, 12 (22.2\%) were secondary school, $17(31.5 \%)$ were high school, 1 (1.9\%) were high school, 4 of them (7.4\%) were university graduates; 14 of the fathers (35\%) primary school, 5 (12.5\%) secondary school, 13 (32.5\%) high school, 2 (5\%) college graduates, $6(15 \%)$ of them are university graduates.

When the WURS scores of the parents were evaluated, it was determined that $12(12.7 \%)$ of the WURS scores were above the cut-off score (36). When the parents' WURS scores were divided into two groups according to their cut-off scores and evaluated in terms of PSDS-SF scores; it was determined that the permissive subscale score of PSDS-SF was significantly higher in the parents whose WURS score was above the cut-off score compared to the parents whose WURS score was below the cut-off score $(p=0.04)$ (Table 1).

When the parents' scale scores were evaluated separately as parents, there was no statistically significant difference between the parents' WURS and PSDS-SF scores ( $p>0.05$ ) (Table 2).

When the relationship between the age and education levels of mothers and fathers and PSDS-SF scores were examined; There was no significant relationship between age and education levels and PSDS-SF scores ( $p>0.05$ ) (Table 3).

\section{Table 1. Assessment of parents' PSDS-SF scores based on WURS cut-off scores}

\begin{tabular}{|c|c|c|c|}
\hline & WURS >36 $($ mean \pm SD $)$ & WURS $<36($ mean \pm SD $)$ & $p$ \\
\hline \multicolumn{4}{|l|}{ PSDS-SF } \\
\hline Competent & $57.08 \pm 12.10$ & $56.68 \pm 11.38$ & 0.82 \\
\hline Permissive & $15.17 \pm 3.71$ & $12.84 \pm 3.48$ & $0.04^{*}$ \\
\hline
\end{tabular}

\section{Table 2. Assessment of parents in terms of WURS, PSDS-SF scores}

\begin{tabular}{|c|c|c|c|c|}
\hline & & Mother $(n=54)($ mean \pm SD) & Father $(n=40)($ mean \pm SD $)$ & $p$ \\
\hline \multicolumn{2}{|l|}{ WURS } & $18.69 \pm 12.08$ & $22.43 \pm 14.76$ & 0.18 \\
\hline \multirow{2}{*}{ PSDS-SF } & Competent & $58.07 \pm 11.48$ & $54.93 \pm 11.21$ & 0.18 \\
\hline & Permissive & $13.48 \pm 3.66$ & $12.67 \pm 3.44$ & 0.28 \\
\hline
\end{tabular}

Table 3. Relationship between age and education levels of parents and PSDS-SF scores

\begin{tabular}{|c|c|c|c|c|c|c|}
\hline & \multicolumn{6}{|c|}{ PSDS-SF } \\
\hline & \multicolumn{2}{|c|}{ Competent } & \multicolumn{2}{|c|}{ Authoritarian } & \multicolumn{2}{|c|}{ Permissive } \\
\hline & $r$ & $p$ & $r$ & $p$ & $r$ & $p$ \\
\hline Age & -0.094 & 0.36 & 0.017 & 0.86 & 0.009 & 0.93 \\
\hline Education level & 0.071 & 0.49 & -0.061 & 0.55 & 0.001 & 0.99 \\
\hline
\end{tabular}




\section{DISCUSSION}

According to the results of our study; parents with high ADHD symptom levels were found to have significantly higher permissive parental attitudes than parents with low ADHD symptoms, and there was no significant difference between the two groups in terms of competent and authoritarian attitudes. No significant association was found between parental attitudes and the age and educational level of parents. In addition, comparisons of parents in terms of ADHD symptom level and parental attitudes did not show significant differences between parents in terms of both variables.

Studies show that parents with ADHD are associated with signs and symptoms of ADHD and negative parental attitudes. Fortyfour months of age with an average of 258 children and their parents with a 3-year longitudinal study, mothers' levels of ADHD and ADHD symptoms in children examined early and late-term relationship with parental attitudes; mothers with high levels of ADHD symptoms of excessive reactive attitudes (over-reactive parenting) demonstrated by mothers of ADHD in children, ADHD symptoms and higher symptom levels in terms of late-term negative parental attitudes are found to be the decisive factors (29). A study conducted by Woods et al. (30) found that 79 children and their mothers with an age range of 5-10 were positively associated with maternal ADHD symptoms; high control level, low temperature (harsh parenting) parental attitudes, and there was no significant association between maternal ADHD levels and positive parental attitudes (30). A meta-analysis study that examined 32 studies on the subject found that negative parental attitudes and ADHD symptom levels were associated; their parents displayed high levels of control (hars parenting) and/or low levels of control and control (lax parenting) as ADHD levels increased.

In addition, it was determined that there was no significant relationship between parents' ADHD level and positive parental attitudes (31). In Turkey, 87 children with ADHD and a thesis study with 84 healthy control group; it has been found that mothers in the ADHD group exhibit more authoritarian and permissive attitudes than mothers in the control group, and ADHD symptom levels of mothers are associated with negative parental attitudes (26). In our study, parents with high levels of ADHD symptoms according to parents with a low level of ADHD symptoms, permissive attitudes to high levels of authoritarian attitudes and positive (competent) have been found to show significant differences in terms of parental attitudes. Our results, partially compatible with the literature, suggest that ADHD signs and symptoms negatively affect parental attitudes. ADHD is a disorder that causes attention deficit, difficulty in executive function, impulsivity, and difficulty in controlling emotions and behaviors (8). It is believed that possible difficulties in ADHD-induced control mechanisms and behavior regulation can prevent parents from developing stable attitudes in their relationship with their children, causing them to behave more permissively and unsupervised.
In studies conducted in children with ADHD, it was found that parental attitudes are associated with many variables. A study conducted by Silva and colleagues found that while the relationship between the attitudes of 68 parents with children with ADHD between the ages of 6 and 11 was not found, it was directly related to critical/rejecting and permitting/negligent parental attitudes and additional behavioral problems in children (32). One hundred three ADHD children and their mothers in Turkey with ADHD subtypes in a study examined the relationship between parental attitudes; it was determined that children in the careless and compound subtype perceive their parents as more permissive/negligent, while children with the hyperactive subtype perceive their parents as more authoritarian (22). A recent crosssectional study conducted in Turkey, which examined 58 ADHD, 30 healthy children and their parents, found that children in the ADHD group perceive their maternal and paternal attitudes as less relevant, unsupervised and more strict discipline than the control group. In the same study, it was determined that variables such as children's gender, ADHD symptom level, comorbidity had significant effects on parental attitudes; When the mother's age was controlled, it was observed that the difference between the children with ADHD and healthy children in terms of perceived parental attitudes did not change (18). In our study, no significant association was found between parental attitudes and the age and educational levels of parents. Although our results are consistent with the literature, the lack of a healthy control group in our study is a significant limitation in terms of interpretation of our results.

When the literature was examined, it was seen that mostly only mothers were evaluated in studies examining parents' ADHD symptoms and parental attitudes $(10,14,30,33,34)$. Our study is one of the few studies that evaluated the ADHD symptom levels of mothers and fathers separately $(13,15,35-38)$. A study conducted with 109 of the mothers and fathers of children with an age range of 2-12 followed by the diagnosis of ADHD found no significant difference between the level of ADHD symptoms and parental attitudes of parents (39). Similarly, the results of our study found that parents did not differ significantly in terms of ADHD symptom level and parental attitudes. It is believed that large sample studies are needed to interpret our results.

\section{Study Limitations}

Our study has some limitations. The small sample size of our study and the lack of a healthy control group are limitations. ADHD is a clinical diagnosis, but in our study, parents were evaluated for ADHD only with diagnostic tools with high validity and reliability. It is an important limitation that parents have not been made diagnostic evaluations by a psychiatrist in terms of both ADHD and other possible psychopathologies. The fact that future studies on this issue have a design with a wide sample, in which parents are evaluated in terms of co-diagnoses with a high incidence of ADHD, as well as the severity of children's ADHD symptoms, will increase the interpretability of the results. 


\section{CONCLUSION}

In the results of our study; parents of children diagnosed with ADHD have more permissive attitudes, parents with high ADHD symptom levels and parents with low ADHD symptoms do not differ in authoritarian and competent attitudes, and there is a significant difference between mothers and fathers in terms of ADHD level and parental attitudes. It was found that there was no difference between the parents' age and education levels and their attitudes. Parental attitudes play an important role in the severity of symptoms in ADHD, accompanying psychiatric diseases, and the prognosis of the disorder. ADHD in children negatively affects parents' parenting skills. The results of our study suggest that the symptoms of ADHD of parents in children with ADHD should also be considered as another factor that negatively affects their parenting skills. It is known that multiple approach models, including psychopharmacological treatments for the clinical treatment of ADHD, as well as evaluation of parents' attitude and behavior patterns and necessary psychosocial interventions, are the most effective treatment methods. During the treatment process, interventions for the parents' attitudes; it is thought that evaluation of mother and/or father in terms of ADHD and psychoeducation about adult ADHD is important.

Ethics Committee Approval: The study was approved by the Ankara University Faculty of Medicine Ethics Committee (approval number: 9.02.2012).

Informed Consent: The children and their parents in the study group were informed about the purpose and method of the study and their written consents were obtained.

Peer-review: Externally peer-reviewed.

Author Contributions: Concept - Ö.Ş.B., M.Ç., Z.E.U., B.G.K.; Design Ö.S..B., M.Ç., Z.E.U., B.G.K.; Data Collection and/or Processing - Ö.Ş.B., M.Ç., Z.E.U.; Analysis and/or Interpretation - Ö.Ş.B., M.Ç., B.G.K.; Literature Search - Ö.Ş.B., M.Ç., B.G.K.; Writing Manuscript - Ö.Ş.B., M.Ç.

Conflict of Interest: The authors have no conflict of interest to declare.

Financial Disclosure: The authors declared that this study has received no financial support.

\section{REFERENCES}

1. Willcutt EG. The prevalence of DSM-IV attention-deficit/hyperactivity disorder: a meta-analytic review. Neurotherapeutics 2012; 9: 490-9.

2. Fayyad J, De Graaf R, Kessler R, Alonso J, Angermeyer M, Demyttenaere $K$, et al. Cross-national prevalence and correlates of adult attentiondeficit hyperactivity disorder. Br J Psychiatry 2007; 190: 402-9.

3. Hechtman L, McGough JJ. Dikkat Eksikliği Bozuklukları. In: Kaplan \& Sadock's Comprehensive Textbook of Psychiatry (Translation Öner Ö, Aysev A.), Ankara, Güneş Tıp Kitabevi, 2007, p.3183-205.

4. Aydın H, Diler RS, Yurdagül E, Uğuz Ş, Şeydaoğlu G. DEHB tanılı çocukların ebeveynlerinde DEHB oranı. Klin Psikiyatr Derg 2006; 9: 70-4.

5. Güvendeğer Doksat N, Balkanlı Zengin H, Doksat MK. Dikkat eksikliği ve hiperaktivite bozukluğu olan çocukların ebeveynlerinde mükemmeliyetçilik ve dikkat eksikliği ve hiperaktivite bozukluğu. Cukurova Med J 2018; 43: 581-8.

6. Kessler RC, Adler L, Barkley R, Biederman J, Conners CK, Demler O, et al. The prevalence and correlates of adult ADHD in the United States: results from the National Comorbidity Survey Replication. Am J Psychiatry 2006; 163: 716-23

7. Simon V, Czobor P, Bálint S, Mészáros A, Bitter I. Prevalence and correlates of adult attention-deficit hyperactivity disorder: meta-analysis. Br J Psychiatry J Ment Sci 2009; 194: 204-11.
8. Surman $\mathrm{CBH}$, Biederman J, Spencer $\mathrm{T}$, Miller CA, McDermott KM, Faraone SV. Understanding deficient emotional self-regulation in adults with attention deficit hyperactivity disorder: a controlled study. ADHD Attention Deficit and Hyperactivity Disorders 2013; 5: 273-81.

9. Lin YJ, Lo KW, Yang LK, Gau SF. Validation of DSM-5 age-of-onset criterion of attention deficit/hyperactivity disorder (ADHD) in adults: comparison of life quality, functional impairment, and family function. Res Dev Disabil 2015; 47: 48-60.

10. Efron D, Furley K, Gulenc A, Sciberras A. Maternal ADHD symptoms, child ADHD symptoms and broader child outcomes. Arch Dis Child 2018; 103: $841-6$

11. Baumrind D. Current patterns of parental authority. Dev Psychol 1971; 4: 1-103.

12. Sümer N, Gündoğdu Aktürk E, Helvacı E. Psychological effects of parenting styles and behaviors: a review of studies in Turkey. Turkish Psychological Articles 2010; 13: 60-1.

13. Starck M, Grünwald J, Schlarb AA. Occurrence of ADHD in parents of ADHD children in a clinical sample. Neuropsychiatr Dis Treat 2016; 12: 581-8.

14. Babinski DE, Pelham WE, Molina BSG, Gnagy EM, Waschbusch DA, Wymbs BT, et al. Maternal ADHD, parenting and psychopathology among mothers of adolescents with ADHD. J Atten Disord 2012; 20: 45868.

15. Karbalaei Sabagh A, Khademi M, Noorbakhsh S, Razjooyan K, Arabgol F. Adult attention deficit hyperactivity disorder and parenting styles. Indian J Pediatr 2015; 83: 254-57.

16. Barkley RA, Fischer M, Edelbrock C, Smallish L. The adolescent outcome of hyperactive children diagnosed by research criteria-III. Mother-child interactions, family conflicts and maternal psychopathology. J Child Psychol Psychiatr 1991; 32: 233-55.

17. Çengel Kültür SE, Öztekin C. Dikkat eksikliği/hiperaktivite bozukluğu ve yıkıcı davranış sorunlarının tedavisinde anne-babalık becerileri. Turkiye Klinikleri J Child Psychiatry-Special Topics 2017; 3: 106-14.

18. Çöp E, Çengel Kültür SE, Dinç Şenses G. Ana babalık tutumları ile dikkat eksikliği ve hiperaktivite bozukluğu belirtileri arasındaki ilişki. Turk Psikiyatri Derg 2017; 28: 25-32.

19. Yalçın H, Karaman HN. Dikkat eksikliği hiperaktivite bozukluğu olan 6-12 yaş çocukların aile tutumlarının değerlendirilmesi. ACED Uluslararası Aile Çocuk ve Eğitim Derg 2018; 15: 84-99.

20. Uzun ME, Uçar HN, Vural AP. Dikkat eksikliği ve hiperaktivite bozukluğu olan ergenlerde bağlanma özellikleri ve ebeveyn tutumları. JCP 2019; 17: 289-300.

21. Durukan I, Erdem M, Türkbay T, Cöngöloğlu MA. Dikkat eksikliği hiperaktivite bozukluğu olan çocukların klinik belirtilerinin annelerinin öfke düzeyleri ve öfke ifade tarzları ile ilişkisi. Gülhane Tıp Derg 2009; 51: 101-4.

22. Ertuğrul G, Toros F. Dikkat eksikliği hiperaktivite bozukluğu olan ergenlerin algıladıkları ebeveyn tutumu ve ebeveynlerinin evlilik uyumları arasındaki ilişki. Yeni Symposium 2010; 48: 172-83.

23. Polat H. Dikkat eksikliği hiperaktivite bozukluğu tanısı almış çocukların annelerinin algıladıkları sosyal destek düzeyleri, tükenmişlik düzeyleri ve cocuk yetiştirme tutumlarının incelenmesi. Yüksek Lisans Tezi. Atatürk Üniversitesi Sağlık Bilimleri Enstitüsü, 2015.

24. Türe F. Dikkat eksikliği ve hiperaktivite bozukluğu olan çocukların (8-12 yaş) değişik anne tutumlarına göre benlik saygı düzeylerinin incelenmesi. Yüksek Lisans tezi, Maltepe Üniversitesi Sosyal Bilimler Enstitüsü Klinik Psikoloji Anabilim Dalı, 2010.

25. Uçar HN, Vural AP. Irritability and parenting styles in adolescents with attention-deficit/hyperactivity disorder: a controlled study. J Psychosoc Nurs Ment Health Serv 2018; 56: 33-43.

26. Keser N. Dikkat eksikliği ve hiperaktivite bozukluğu tanısı almış ve almamış çocukların duygu ayarlama, anne baba tutumları, annenin dehb belirti ve bulgu düzeyinin incelenmesi. Yüksek Lisans Tezi, Ankara Üniversitesi Eğitim Bilimleri Enstitüsü, 2010.

27. Öncü B, Ölmez Ş, Şentürk V. Wender-Utah Derecelendirme Ölçeğ Türkçe Formunun erişkin dikkat eksikliği ve hiperaktivite bozukluğus nda geçerlik ve güvenilirlik çalışması. Türk Psikiyatr Derg 2005; 16: 252-9.

28. Kapçı EG, Erdinç S. Anne-baba tutum ölçeğinin 3-13 yaş aralığında çocuğu bulunan annelerde değerlendirilmesi. 18. Ulusal Eğitim Bilimleri Kurultayı, Bildiri Kitabı, İzmir, 2009 
29. Breaux RP, Brown HR, Harvey EA. Mediators and moderators of the relation between parental ADHD symptomatology and the early development of child ADHD and ODD symptoms. J Abnorm Child Psychol 2016; 45: 443-56.

30. Woods KE, Mazursky-Horowitz H, Thomas SR, Dougherty LR, ChronisTuscano A. The unique effects of maternal ADHD symptoms and emotion dysregulation on parenting behavior. J Atten Disord 2019.

31. Park JL, Johnston C. Parental ADHD symptoms and parenting behaviors. The ADHD Report 2019; 27: 1-7.

32. Muñoz-Silva A, Lago-Urbano R, Sanchez-Garcia M. Family impact and parenting styles in families of children with ADHD. J Child Fam Stud 2017; 26: 2810-23.

33. Murray $\mathrm{C}$, Johnston C. Parenting in mothers with and without attentiondeficit/ hyperactivity disorder. J Abnorm Child Psychol 2006; 115: 52-61.

34. Algorta GP, Kragh CA, Arnold LE, Molina BSG, Hinshaw SP, Swanson JM, et al. Maternal ADHD symptoms, personality and parenting stress: differences between mothers of children with ADHD and Mothers of Comparison Children. J Atten Disord 2018; 22:1266-77.
35. Psychogiou L, Daley D, Thompson M, Sonuga-Barke E. Testing the interactive effect of parent and child ADHD on parenting in mothers and fathers: a further test of the similarity-fit hypothesis. $\mathrm{Br} J \mathrm{Dev}$ Psychol 2007; 25: 419-33.

36. Williamson D, Johnston C, Noyes A, Stewart K, Weiss MD. AttentionDeficit/Hyperactivity Disorder symptoms in mothers and fathers: family level interactions in relation to parenting. J Abnorm Child Psychol 2017; 45: 485-500.

37. Friedrich A, Moning J, Weiss J, Schlarb A. The effects of parental ADHD symptoms on parenting behaviors. Health 2017; 9: 1054-74.

38. Wymbs BT, Wymbs FA, Dawson AE. Child ADHD and ODD behavior interacts with parent ADHD symptoms to worsen parenting and interparental communication. J Abnorm Child Psychol 2014; 43: 107-19.

39. Jeppson-Frandsen R. Adult Attention-Deficit/Hyperactivity Disorder (ADHD): relationship between parental symptomatology, child behaviors, and parenting behaviors. Unpublished Thesis, Utah State University, 2019. 